\title{
THE PERCEPTION OF TOURIST ELDERLY VISIT TO ANCOL
}

\author{
Kania Ratnasari \\ Universitas Sahid Jakarta \\ Email: kania.ratnasari@yahoo.com \\ Susy Bhudiharty \\ Universitas Sahid Jakarta \\ Email: susybhudiharty@gmail.com
}

\begin{abstract}
This study aims to find out the profile of elderly tourists who come to visit Ancol Beach, find out how important attributes / facilities Ancol Coast needed by elderly tourists, knowing the performance of the attributes / facilities provided by the Ancol and know how the perception of elderly tourists in a visit to the Beach Ancol. The method used for this research is the method of Importance Performance Analysis (IPA) by using Cartesian diagram. Data collection techniques obtained through interviews and questionnaires distributed for elderly visitors as many as 40 people. Data processing using the calculation of the average importance and performance, the calculation of the level of conformity followed by the making of Cartesian diagram. Results of the calculation of the level of interests and performance of visitors Ancol Coast by using the level of conformity that indicates a mismatch between expectations with the reality of respondents. Thus, the existing attributes have not been able to give satisfaction to the visitors of Ancol Beach. From the side of Cartesian diagram, there are 11 attributes that enter into Quadrant I and there are 2 attributes that enter into Quadrant II, whereas there is not one attribute that enter into Quadrant III and IV. The ideal attributes are in quadrant II for attributes of fresh coastal air climate and café / resto availability.
\end{abstract}

Keywords: Perception, Elderly Travelers, Important Performance Analysis (IPA), Cartesian Diagram, Ancol Beach 


\section{PENDAHULUAN}

Pariwisata adalah berbagai macam kegiatan wisata yang didukung oleh berbagai macam fasilitas serta layanan yang disediakan oleh masyarakat, pengusaha, pemerintah daerah, dan pemerintah pusat. Potensi wisata yang ada, akan menjadi peluang besar dalam pengembangan pariwisata yang diharapkan dapat memberikan manfaat besar bagi kesejahteraan dan peningkatan perekonomian masyarakat sekitar dimasa yang akan datang. Untuk mensukseskan penyelenggaraan pariwisata oleh pemerintah agar sesuai dengan permintaan pasar, maka dibutuhkan data tentang wisatawan yang meliputi karakteristik demografi wisatawan: jenis kelamin, umur, tempat asal, pekerjaan.

Tabel 1. Jumlah Remaja dan Lansia Wilayah DKI Jakarta

\begin{tabular}{|c|c|c|c|c|c|c|c|c|c|c|}
\hline \multicolumn{11}{|c|}{ JUMLAH JIWA MENURUT KELOMPOK BALITA, REMAJA DAN LANSIA } \\
\hline \multirow[t]{2}{*}{$\begin{array}{l}\mathbf{N} \\
\text { O. }\end{array}$} & \multirow[t]{2}{*}{ KABUPATEN } & \multirow{2}{*}{$\begin{array}{c}\text { JML } \\
\text { H } \\
\text { JIWA }\end{array}$} & \multicolumn{2}{|c|}{$\begin{array}{l}\text { BALITA }(0- \\
<5 \text { TAHUN })\end{array}$} & \multicolumn{2}{|c|}{$\begin{array}{l}\text { REMAJA (16- } \\
24 \text { TAHUN) }\end{array}$} & \multicolumn{2}{|c|}{$\begin{array}{c}\text { LANSIA (60+ } \\
\text { TAHUN) }\end{array}$} & \multicolumn{2}{|c|}{ TOTAL } \\
\hline & & & $\underset{\mathbf{H}}{\mathrm{JML}}$ & $\%$ & $\begin{array}{c}\mathbf{J M L} \\
\mathbf{H}\end{array}$ & $\%$ & $\begin{array}{c}\mathbf{J M L} \\
\mathbf{H}\end{array}$ & $\%$ & $\underset{\mathbf{H}}{\mathrm{JML}}$ & $\%$ \\
\hline 1 & 2 & 3 & 4 & 5 & 6 & 7 & 8 & 9 & 10 & 11 \\
\hline 1 & Jakarta Pusat & 58 & 3 & $\begin{array}{r}10.7 \\
\%\end{array}$ & 13 & $\begin{array}{r}46.43 \\
\%\end{array}$ & 12 & $\begin{array}{r}42.86 \\
\%\end{array}$ & 28 & $\begin{array}{r}48.28 \\
\%\end{array}$ \\
\hline 2 & Jakarta Utara & 3155 & 52 & $4.3 \%$ & 771 & $\begin{array}{r}63.72 \\
\%\end{array}$ & 387 & $\begin{array}{r}31.98 \\
\%\end{array}$ & 1210 & $\begin{array}{r}38.35 \\
\%\end{array}$ \\
\hline 3 & Jakarta Barat & 1633 & 0 & $0.0 \%$ & 4 & $1.96 \%$ & 200 & $\begin{array}{r}98.04 \\
\%\end{array}$ & 204 & $\begin{array}{r}12.49 \\
\%\end{array}$ \\
\hline 4 & Jakarta Selatan & $\begin{array}{r}46589 \\
4\end{array}$ & $\begin{array}{r}1604 \\
5\end{array}$ & $9.2 \%$ & $\begin{array}{r}11568 \\
3\end{array}$ & $\begin{array}{r}66.78 \\
\%\end{array}$ & $\begin{array}{r}4149 \\
9\end{array}$ & $\begin{array}{r}23.96 \\
\%\end{array}$ & $\begin{array}{r}1732 \\
27\end{array}$ & $\begin{array}{r}37.18 \\
\%\end{array}$ \\
\hline 5 & Jakarta Timur & 387 & 6 & $4.5 \%$ & 111 & $\begin{array}{r}83.46 \\
\%\end{array}$ & 16 & $\begin{array}{r}12.03 \\
\%\end{array}$ & 133 & $\begin{array}{r}34.37 \\
\%\end{array}$ \\
\hline 6 & $\begin{array}{l}\text { Kepulauan } \\
\text { Seribu }\end{array}$ & 0 & 0 & $0.0 \%$ & 0 & $0.00 \%$ & 0 & $0.00 \%$ & 0 & $0.00 \%$ \\
\hline & JUMLAH & $\begin{array}{r}47112 \\
7\end{array}$ & $\begin{array}{r}1610 \\
6\end{array}$ & $\begin{array}{r}9.21 \\
\%\end{array}$ & $\begin{array}{r}11658 \\
2\end{array}$ & $\begin{array}{r}66.69 \\
\%\end{array}$ & $\begin{array}{r}4211 \\
4\end{array}$ & $\begin{array}{r}24.09 \\
\%\end{array}$ & $\begin{array}{r}1748 \\
02\end{array}$ & $\begin{array}{r}37.10 \\
\%\end{array}$ \\
\hline
\end{tabular}

Menurut data diatas, terlihat bahwa jumlah lansia di wilayah Jakarta mencapai total sebesar 24.09\%. Taman Impian Jaya Ancol adalah sebuah kawasan terpadu wisata dan juga sebuah objek wisata di Jakarta Utara yang menawarkan sajian hiburan berkualitas yang berunsur seni, budaya dan pengetahuan. Taman Impian Jaya Ancol ini menjadi tempat obyek wisata yang terkenal di Jakarta karena lokasi dan obyek wisata yang ditawarkannya sangat menarik salah satunya 
yaitu adanya Pantai Ancol. Taman Impian Jaya Ancol menyediakan wisata yang beragam di dalam satu kawasan tersebut. Selain sebagai tempat berlibur, kawasan pantai di Taman Impian Jaya Ancol juga digunakan untuk berolahraga pagi seperti aktivitas berolahraga di jembatan pantai Ancol pada hari Sabtu dan Minggu pagi, sejak pukul 05.00 sampai pukul 10.00, hampir semua sisi pantai Ancol menjadi tempat berolahraga.

Wisatawan yang berkunjung ke Taman Impian Jaya Ancol biasanya tidak hanya mempunyai tujuan untuk menikmati berbagai wahana yang terdapat disana tetapi juga ingin merasakan suasana pantai yang terdapat di dalam Kawasan Wisata Taman Impian Jaya Ancol. Wisatawan yang berkunjung ke tempat wisata ini sebagian besar didominasi oleh anak-anak, namun tidak sedikit pula pengunjung dewasa, remaja,dan lansia untuk menikmati wisata di Taman Impian Jaya Ancol tersebut.

Tujuan dari penelitian ini yaitu untuk mengetahui profil wisatawan lansia yang datang berkunjung ke Pantai Ancol, mengetahui seberapa pentingnya atribut/fasilitas Pantai Ancol yang dibutuhkan oleh wisatawan lansia, mengetahui kinerja dari atribut/fasilitas yang disediakan oleh pihak Ancol dan mengetahui bagaimana persepsi wisatawan lansia dalam berkunjung ke Pantai Ancol.

\section{KAJIAN TEORI}

\section{Pengertian Persepsi}

Setiap orang mempunyai kecenderungan dalam melihat benda yang sama dengan cara yang berbeda-beda. Perbedaan tersebut bisa dipengaruhi oleh banyak faktor, diantaranya adalah pengetahuan, pengalaman dan sudut pandangnya. Persepsi juga bertautan dengan cara pandang seseorang terhadap suatu objek tertentu dengan cara yang berbeda-beda dengan menggunakan alat indera yang dimiliki, kemudian berusaha untuk menafsirkannya. Persepsi baik positif maupun negatif ibarat file yang sudah tersimpan rapi di dalam alam pikiran bawah sadar kita. File itu akan segera muncul ketika ada stimulus yang memicunya, ada kejadian yang membukanya. Persepsi merupakan hasil kerja otak dalam memahami atau menilai suatu hal yang terjadi di sekitarnya (Waidi, 2006: 118) 
sedangkan menurut Robbins (2008: 175), persepsi adalah suatu proses yang ditempuh individu-individu untuk mengorganisasikan dan menafsirkan kesan indera mereka agar memberi makna kepada lingkungan mereka. Terkadang apa yang dipersepsikan oleh seseorang tidak sesuai dengan kenyataan secara objektif.

\section{Perilaku Wisatawan}

Para ahli mendefinisikan perilaku wisatawan, menurut Morrisan (2007:64) perilaku wisatawan adalah proses dan kegiatan yang terlibat ketika orang mencari, memilih, menggunakan, mengevaluasi, dan membuang produk dan jasa untuk memuaskan kebutuhan dan keinginan mereka. Bidang ilmu perilaku wisatawan (tourist behavior) mempelajari bagaimana individu, kelompok, dan organisasi memilih, membeli, memakai, serta memanfaatkan suatu produk dalam rangka memuaskan kebutuhan dan keinginan wisatawan.

Perilaku wisatawan menurut Hasan (2008:129) adalah respon psikologis yang kompleks yang muncul dalam bentuk perilaku atau tindakan yang khas secara perseorangan yang langsung terlibat dalam usaha memperoleh dan menggunakan produk serta menentukan proses pengambilan keputusan dalam melakukan pembelian produk termasuk dalam melakukan pembelian ulang, yang dimaksud adalah wisatawan berkunjung ke daerah tujuan wisata, membeli souvenir, dan suatu saat wisatawan tersebut kembali berkunjung karena merasa nyaman dan percaya.

\section{Manusia Lanjut Usia (Manula)}

Manusia lanjut usia atau yang biasa disingkat dengan istilah lansia adalah manusia yang berusia 60 (enam puluh) tahun ke atas. Menurut UU RI No.12 tahun 1998, Lansia (lanjut usia) adalah seseorang yang telah mencapai usia diatas 60 tahun. Sementara menurut WHO, kelompok Lansia meliputi mereka yang berusia 60-74, Lansia tua 75-90 tahun serta Lansia sangat tua di atas 90 tahun. WHO memperkirakan tahun 2025 jumlah lansia di seluruh dunia akan mencapai 1,2 miliar orang yang akan terus bertambah hingga 2 miliar orang di tahun 2050 .

Data WHO juga memperkirakan $75 \%$ populasi lansia di dunia pada tahun 2025 berada di negara berkembang.Hasil Sensus Penduduk tahun 2010 menunjukkan bahwa Indonesia termasuk lima besar negara dengan jumlah 
penduduk lanjut usia terbanyak di dunia yakni mencapai 18,1 juta jiwa pada 2010 atau 9,6\% dari jumlah penduduk (liputan6.com, 24 Mar 2013).Data Susenas BPS 2012 menunjukkan lansia di Indonesia sebesar 7,56\% dari total penduduk Indonesia. Menurut data tersebut sebagian besar lansia di Indonesia berjenis kelamin perempuan. (kompasiana, 29 mei 2014). Bappenas memperkirakan pada tahun 2050 akan ada 80 juta lansia di Indonesia dengan komposisi usia 60-69 tahun berjumlah 35,8 juta, usia 70-79 tahun berjumlah 21,4 juta dan 80 tahun ke atas ada 11,8 juta.

Dilihat dari segi usia wisatawan yang beragam, Pasar Orang Tua (senior market) merupakan kelompok penting karena besarnya pasar dan potensialnya untuk berkembang. Pemerintah Indonesia mengganggap wisatawan senior atau lanjut usia adalah pangsa pasar yang cukup penting karena beberapa alasan, di antaranya adalah:Dengan kemajuan teknologi, sistem kesehatan dan semakin panjang jangka waktu hidup seseorang secara langsung meningkatkan jumlah penduduk lanjut usia.Sebab lainnya adalah adanya tunjangan penghasilan dari sistem pensiun yang baik akan dapat menyebabkan kelompok wisatawan senior atau lanjut usiaini menjadi mapan secara finansial dan memiliki daya beli yang lebih baik serta memiliki waktu luang yang sangat besar untuk berlibur.Kelompok ini biasa dikenal dengan istilah DINKS (Double Income No Kids) dan pada fase usia ini, pola berwisata biasanya dilakukan dalam waktu panjang karena waktu luang yang dimilikinya cukup panjang (News Letter Pemasaran Pariwisata Indonesia, 2011). Menurut Wei dan Milman (2002) mengemukakan bahwa aktivitas paling popular yang dilakukan oleh wisatawan lanjut usia yaitu melakukan perjalanan wisata dan berkeliling kota $(89,3 \%)$, mengunjungi tempattempat bersejarah $(88,1 \%)$, makan-makan di restoran $(85,7 \%)$, dan shopping $(77,4 \%)$. Sementara kegiatan yang kurang diminati adalah berburu dan memancing $(1,2 \%)$, olahraga air dan berjemur di pantai $(1,2 \%)$, kemping dan mendaki $(3,6 \%)$. 


\section{METODE PENELITIAN}

\section{Objek Penelitian}

Pengunjung lansia dari Taman Impian Jaya Ancol akan menjadi objek penelitian ini dengan waktu penelitian akan dilakukan pada tahun 2016.

\section{Teknik Sampling (Penentuan jumlah sampel)}

Sampel pada penelitian ini adalah pengunjung lansia sebagai responden dengan kriteria minimal lebih dari satu kali mengunjungi Taman Impian Jaya Ancol dan berumur diatas 60 tahun. Pengambilan sampel dilakukan dengan metode accidental sampling atau responden dipilih berdasarkan kesediaannya untuk mengisi kuesioner dan wawancara pada saat berkunjung ke Ancol.

\section{Alat Pengumpulan Data}

Data penelitian dikumpulkan dengan kuesioner semi terbuka, untuk menjaring data tentang latar belakang sosial, demografi, ekonomi dan data tentang psikografi wisatawan. Kuesioner diberikan kepada wisatawan lansia saat istirahat setelah kegiatan atau menurut kesediaannya. Untuk mengukur persepsi dan penilaian digunakan Skala Likert yang bergerak dari 1 (rendah), 2 (sedang), sampai 3 (tinggi). Tujuan pengambilan data yaitu untuk mengumpulkan data pengunjung mengenai identitas pengunjung, tujuan kunjungan dan perilaku pengunjung terhadap atribut-atribut yang ada di objek wisata.

\section{Analisis Data}

Analisis data yang digunakan menggunakan metode Important Performance Analysis (IPA).Hasil pengumpulan data kemudian dianalisis menggunakan tingkat kesesuaian kemudian menggunakan Importance Performance Analysis (IPA).Tahapan pertama dalam metode Importance Performance Analysis (IPA) adalah menentukan tingkat kesesuaian antara tingkat kepentingan pengunjung (visitor expectation) dan tingkat kinerja kualitas atributatribut yang diteliti melalui perbandingan skor kinerja dengan skor kepentingan menggunakan diagram kartesius yang mana berupa skor penilaian kepentingan dan kinerja total. Masing-masing atribut diposisikan dalam suatu diagram. Skor total penilaian terhadap tingkat kinerja (performance) menunjukkan posisi suatu 
atribut pada sumbu X, sementara posisi atribut pada sumbu Y ditunjukkan oleh skor total tingkat kepentingan (importance) pengunjung terhadap atribut.

\section{HASIL DAN PEMBAHASAN}

\section{Analisis Identitas Pengunjung}

Dibawah ini adalah tabel mengenai rangkuman identitas pengunjung yang datang ke pantai Ancol berdasarkan jenis kelamin, usia, alamat asal, pendidikan, tujuan kunjungan, frekuensi kunjungan, dan pendamping ketika melakukann kunjungan.

Tabel 2. Identitas Pengunjung

\begin{tabular}{|c|c|c|c|}
\hline \multicolumn{4}{|c|}{ Data Pengunjung Berdasarkan } \\
\hline \multirow{22}{*}{ 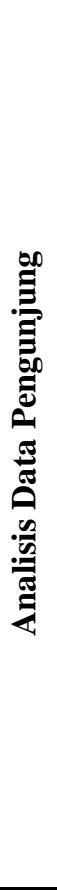 } & Jenis Kelamin & Wanita & $60 \%$ \\
\hline & & Pria & $40 \%$ \\
\hline & Usia & $60-65$ thn & $28 \%$ \\
\hline & & $66-70$ thn & $43 \%$ \\
\hline & & $71-79$ thn & $28 \%$ \\
\hline & & $80-84$ thn & $3 \%$ \\
\hline & Alamat Asal & Jabodetabek & $80 \%$ \\
\hline & & Bandung \& sekitarnya & $15 \%$ \\
\hline & & Luar pulau Jawa & $5 \%$ \\
\hline & Pendidikan & SMP & $5 \%$ \\
\hline & & SMA & $30 \%$ \\
\hline & & Diploma & $5 \%$ \\
\hline & & Sarjana & $60 \%$ \\
\hline & Tujuan Kunjungan & Olahraga & $22 \%$ \\
\hline & & Menikmati pantai & $33 \%$ \\
\hline & & Mencari ketenangan & $8 \%$ \\
\hline & & Mencari hiburan & $37 \%$ \\
\hline & Frekuensi Kunjungan & Sering $>3 x$ & $42 \%$ \\
\hline & & Jarang $<3 \mathrm{x}$ & $58 \%$ \\
\hline & Pendamping ketika berkunjung & Keluarga & $85 \%$ \\
\hline & & Teman-teman & $10 \%$ \\
\hline & & Rekan bisnis & $5 \%$ \\
\hline
\end{tabular}

Sumber: Data Olahan (2016)

Berdasarkan data yang diolah diketahui bahwa dari 40 orang pengunjung yang didapat dari penelitian ini, sebesar $43 \%$ pengunjung yang datang ke pantai Ancol mayoritas adalah pengunjung yang berusia antara 66 tahun sampai dengan 70 tahun berasal dari Jabodetabek sebesar $80 \%$ dan memiliki latar belakang pendidikan yaitu Sarjana sebesar $80 \%$. Mayoritas terbesar pengunjung lansia yang datang ke pantai Ancol memiliki tujuan kunjungan yaitu untuk mencari hiburan sebesar $37 \%$ walaupun mereka jarang $(<3 \mathrm{x})$ melakukan kunjungan ke pantai 
Ancol dengan presentase sebesar 58\%. Apabila berkunjung ke pantai Ancol, para lansia selalu ditemani oleh keluarga dengan presentase sebesar $85 \%$.

\section{Analisis Tingkat Kepentingan}

Analisis tingkat kepentingan atribut digunakan untuk mengetahui tanggapan dari responden yaitu pengunjung lanjut usia (lansia) mengenai tingkat kepentingan atribut yang terdiri dari beberapa indikator. Berikut adalah hasil tanggapan responden mengenai variabel tingkat kepentingan atribut yang diisi oleh 40 orang lansia pengunjung kawasan Ancol.

Tabel 3. Hasil Tanggapan Responden Tentang Variabel Tingkat Kepentingan

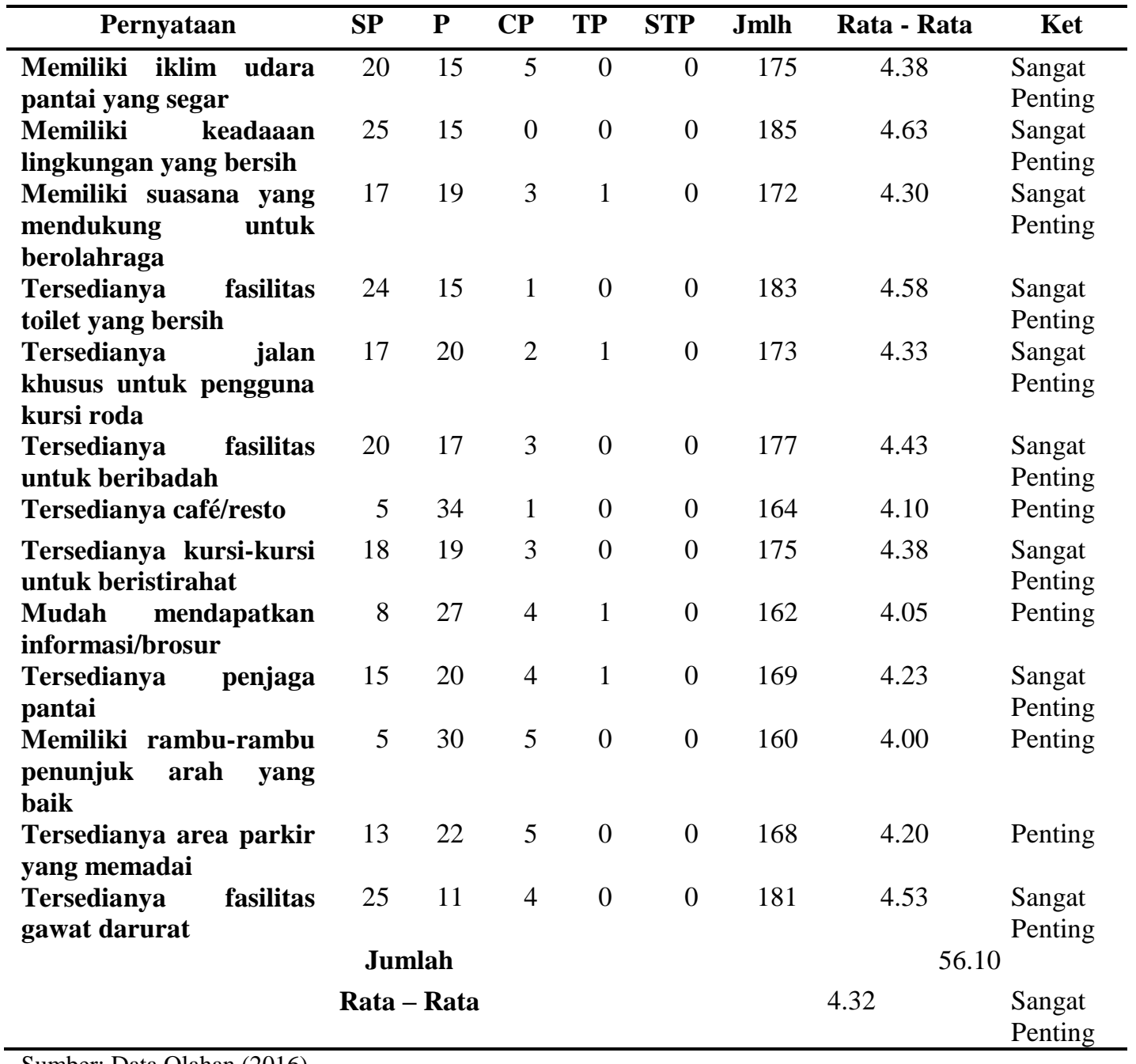


Berdasarkan tabel 3 diatas dapat dilihat bahwa indikator tertinggi yaitu mengenai kebersihan lingkungan sekitar area pantai Ancol dengan nilai rata-rata yaitu 4,63 dimana hal tersebut termasuk kedalam kategori sangat penting.

Hal ini menunjukkan bahwa lingkungan yang bersih merupakan salah satu unsur yang sangat penting bagi para pengunjung lansia ketika melakukan kunjungan ke pantai Ancol sedangkan indikator terendah yaitu mengenai memiliki rambu-rambu penunjuk arah yang baik dengan nilai rata-rata yaitu sebesar 4.00 termasuk kategori penting.

Hal yang menunjukkan bahwa dirasa penting oleh pengunjung lansia apabila pantai Ancol memiliki rambu-rambu penunjuk arah yang baik. Untuk variabel atribut tingkat kepentingan ini diperoleh nilai rata-rata keseluruhan sebesar 4.32 dengan kategori sangat penting. Hal ini menunjukkan bahwa semua atribut yang ada didalam variabel tingkat kepentingan dirasa sangat penting keberadaannya oleh pengunjung lansia.

\section{Analisis Kinerja/Kenyataan}

Analisis evaluasi atribut/kenyataan digunakan untuk mengetahui tanggapan dari responden yaitu pengunjung lanjut usia (lansia) mengenai kenyataan yang dirasakan oleh mereka yang terdiri dari beberapa indikator. Berikut adalah hasil tanggapan responden mengenai variabel evaluasi atribut/kenyataan yang diisi oleh 40 orang lansia pengunjung kawasan Ancol. 
Tabel 4. Hasil Tanggapan Responden Tentang Variabel Tingkat Kenyataan

\begin{tabular}{|c|c|c|c|c|c|c|c|c|c|}
\hline Pernyataan & $\mathbf{S S}$ & $\mathbf{S}$ & $\mathbf{C}$ & TS & STS & Jmlh & $\begin{array}{l}\text { Rata } \\
\text { Rata }\end{array}$ & - & Ket \\
\hline $\begin{array}{l}\text { Memiliki iklim udara pantai } \\
\text { yang segar }\end{array}$ & 15 & 23 & 2 & 0 & 0 & 173 & 4.33 & & $\begin{array}{l}\text { Sangat } \\
\text { Setuju }\end{array}$ \\
\hline $\begin{array}{l}\text { Memiliki keadaaan lingkungan } \\
\text { yang bersih }\end{array}$ & 12 & 24 & 3 & 1 & 0 & 167 & 4.18 & & Setuju \\
\hline $\begin{array}{l}\text { Memiliki suasana yang } \\
\text { mendukung untuk berolahraga }\end{array}$ & 12 & 24 & 3 & 1 & 0 & 167 & 4.18 & & Setuju \\
\hline $\begin{array}{l}\text { Tersedianya fasilitas toilet } \\
\text { yang bersih }\end{array}$ & 2 & 29 & 8 & 1 & 0 & 152 & 3.80 & & Setuju \\
\hline $\begin{array}{l}\text { Tersedianya jalan khusus } \\
\text { untuk pengguna kursi roda }\end{array}$ & 1 & 13 & 18 & 8 & 0 & 127 & 3.18 & & Cukup \\
\hline $\begin{array}{l}\text { Tersedianya fasilitas untuk } \\
\text { beribadah }\end{array}$ & 9 & 28 & 2 & 1 & 0 & 165 & 4.13 & & Setuju \\
\hline Tersedianya café/resto & 10 & 24 & 6 & 0 & 0 & 164 & 4.10 & & Setuju \\
\hline $\begin{array}{l}\text { Tersedianya kursi-kursi untuk } \\
\text { beristirahat }\end{array}$ & 5 & 11 & 18 & 6 & 0 & 135 & 3.38 & & Cukup \\
\hline $\begin{array}{l}\text { Mudah mendapatkan } \\
\text { informasi/brosur }\end{array}$ & 0 & 6 & 22 & 12 & 0 & 114 & 2.85 & & Cukup \\
\hline Tersedianya penjaga pantai & 2 & 33 & 5 & 0 & 0 & 157 & 3.93 & & Setuju \\
\hline $\begin{array}{l}\text { Memiliki rambu-rambu } \\
\text { penunjuk arah yang baik }\end{array}$ & 0 & 15 & 21 & 4 & 0 & 131 & 3.28 & & Cukup \\
\hline $\begin{array}{l}\text { Tersedianya area parkir yang } \\
\text { memadai }\end{array}$ & 8 & 25 & 4 & 3 & 0 & 158 & 3.95 & & Setuju \\
\hline $\begin{array}{l}\text { Tersedianya fasilitas gawat } \\
\text { darurat }\end{array}$ & 3 & 10 & 21 & 6 & 0 & 130 & 3.25 & & Cukup \\
\hline \multicolumn{7}{|c|}{ Jumlah } & \multicolumn{3}{|c|}{48.50} \\
\hline \multicolumn{7}{|c|}{ Rata - Rata } & 3.73 & & Setuju \\
\hline
\end{tabular}

Sumber: Data Olahan (2016)

Berdasarkan tabel 4 diatas dapat dilihat bahwa indikator tertinggi yaitu mengenai pantai Ancol memiliki iklim udara pantai yang segar dengan nilai ratarata yaitu 4,33 dimana hal tersebut termasuk kedalam kategori sangat setuju, yang artinya pengunjung lansia sangat setuju apabila pantai Ancol memiliki iklim udara pantai yang sangat segar sedangkan indikator terendah yaitu mengenai cukup sulitnya mendapatkan informasi/brosur di area sekitar pantai Ancol dengan nilai rata-rata yaitu 2,85 dimana hal tersebut termasuk ke dalam kategori cukup, yang artinya pengunjung lansia cukup sulit mendapatkan informasi/brosur disekitar area pantai Ancol. Untuk variabel atribut evaluasi kenyataan diperoleh nilai ratarata keseluruhan yaitu sebesar 3,73 dimana termasuk kategori setuju. Hal ini menunjukkan bahwa pengunjung lansia setuju mengenai kenyataan yang mereka rasakan dengan kenyataan yang ada di pantai Ancol. 


\section{Analisis Tingkat Kesesuaian Antara Kepentingan dan Kenyataan}

Tingkat kesesuaian merupakan hasil perbandingan antara skor kinerja pelaksanaan dengan skor kepentingan, sehingga tingkat kesesuaian inilah yang akan menentukan skala prioritas

Tabel 5. Tingkat Kesesuaian antara tingkat kepentingan dan kinerja

\begin{tabular}{cccc}
\hline Atribut & $\begin{array}{c}\text { Rata-rata Skor } \\
\text { Kepentingan }\end{array}$ & $\begin{array}{c}\text { Rata-rata Skor } \\
\text { Kinerja }\end{array}$ & $\begin{array}{c}\text { Tingkat Kesesuaian } \\
(\%)\end{array}$ \\
\hline X1 & 4.38 & 4.33 & 98.85 \\
$\mathbf{X 2}$ & 4.63 & 4.18 & 90.28 \\
$\mathbf{X 3}$ & 4.30 & 4.18 & 97.21 \\
$\mathbf{X 4}$ & 4.58 & 3.80 & 82.96 \\
$\mathbf{X 5}$ & 4.33 & 3.18 & 73.44 \\
$\mathbf{X 6}$ & 4.43 & 4.13 & 93.22 \\
$\mathbf{X 7}$ & 4.10 & 4.10 & 100 \\
$\mathbf{X 8}$ & 4.38 & 3.38 & 77.16 \\
$\mathbf{X 9}$ & 4.05 & 2.85 & 70.37 \\
$\mathbf{X 1 0}$ & 4.23 & 3.93 & 92.90 \\
$\mathbf{X 1 1}$ & 4.00 & 3.28 & 82 \\
$\mathbf{X 1 2}$ & 4.20 & 3.95 & 94.04 \\
$\mathbf{X 1 3}$ & 4.53 & 3.25 & 71.74 \\
& Rata - Rata & & 86.47 \\
\hline
\end{tabular}

Sumber: Data Olahan (2016)

Pada tabel 5 di atas dapat diketahui bahwa nilai rata-rata kesesuaian berada pada rentang nilai 80-89 yaitu $86.47 \%$ sehingga dapat disimpulkan secara keseluruhan atribut-atribut tersebut masuk dalam kategori tidak sesuai atau pengunjung tidak merasa puas.

\section{Pengolahan Data Dengan IPA (Importance Performance Analysis)}

Sebelum menjabarkan kedalam diagram kartesius, terlebih dahulu mengetahui tingkat kepentingan-kinerja yang didapat dari rata-rata dari ekspektasi atau tingkat kepentingan dari masing-masing responden tiap atribut (Y) dan rata rata dari persepsi atau kinerja dari masing-masing responden tiap atribut (X). Data tersebut kemudian dijabarkan dalam diagram kartesius, sehingga akan diketahui letak kuadran dari masing-masing atribut. 
Tabel 6. Rata-rata tingkat kepentingan, kinerja, dan letak kuadran atribut

\begin{tabular}{|c|c|c|c|c|}
\hline \multirow{2}{*}{$\begin{array}{c}\text { Atribu } \\
\mathbf{t}\end{array}$} & \multirow[t]{2}{*}{ Pernyataan } & \multicolumn{2}{|c|}{ Mean } & \multirow{2}{*}{$\begin{array}{c}\text { Letak } \\
\text { Kuadra } \\
\text { n }\end{array}$} \\
\hline & & Kepentingan & Kinerja & \\
\hline $\mathbf{X 1}$ & Memiliki iklim udara pantai yang segar & 4.38 & 4.33 & B \\
\hline $\mathbf{X} 2$ & Memiliki keadaaan lingkungan yang bersih & 4.63 & 4.18 & A \\
\hline $\mathbf{X 3}$ & $\begin{array}{l}\text { Memiliki suasana yang mendukung untuk } \\
\text { berolahraga }\end{array}$ & 4.30 & 4.18 & A \\
\hline $\mathbf{X} 4$ & Tersedianya fasilitas toilet yang bersih & 4.58 & 3.80 & A \\
\hline X5 & $\begin{array}{l}\text { Tersedianya jalan khusus untuk pengguna } \\
\text { kursi roda }\end{array}$ & 4.33 & 3.18 & A \\
\hline X6 & Tersedianya fasilitas untuk beribadah & 4.43 & 4.13 & A \\
\hline $\mathbf{X 7}$ & Tersedianya café/resto & 4.10 & 4.10 & B \\
\hline X8 & Tersedianya kursi-kursi untuk beristirahat & 4.38 & 3.38 & A \\
\hline X9 & Mudah mendapatkan informasi/brosur & 4.05 & 2.85 & A \\
\hline $\mathbf{X 1 0}$ & Tersedianya penjaga pantai & 4.23 & 3.93 & A \\
\hline X11 & $\begin{array}{l}\text { Memiliki rambu-rambu penunjuk arah yang } \\
\text { baik }\end{array}$ & 4.00 & 3.28 & A \\
\hline $\mathbf{X 1 2}$ & Tersedianya area parkir yang memadai & 4.20 & 3.95 & A \\
\hline $\mathbf{X 1 3}$ & Tersedianya fasilitas gawat darurat & 4.53 & 3.25 & A \\
\hline
\end{tabular}

Sumber: Data Olahan (2016)

Cara membuat diagram kartesius adalah, membagi suatu bagan menjadi empat bagian yang dibatasi oleh dua buah garis yang berpotongan tegak lurus pada titik-titik $X, Y$, dimana $X$,merupakan rata-rata dari rata-rata skor tingkat pelaksanaan atau kinerja kepuasan pengguna atas seluruh atribut, dan $Y$, adalah rata-rata dari rata-rata skor tingkat kepentingan seluruh atribut yang mempengaruhi kepuasan pengguna.

\section{Analisis Tingkat Kepentingan Dan Kinerja}

Rata-rata persepsi tiap atribut merupakan dasar untuk menentukan apakah kinerja Pantai Ancol sudah baik atau belum pada atribut tersebut yaitu dengan membandingkan rata-rata seluruh atribut (X) dan hasilnya diperoleh sebesar 3,73. Rata-rata harapan tiap atribut merupakan dasar untuk menentukan apakah atribut tersebut penting atau tidak penting, yaitu dengan membandingkan rata-rata seluruh atribut (Y) dan hasilnya diperoleh sebesar 4,32. Nilai rata-rata kepentingan dan kinerja tersebut digunakan untuk menganalisis data dalam diagram kartesius pada Gambar 1 dibawah ini. Berikut adalah penjabaran setiap atribut dalam diagram Kartesius yaitu: 


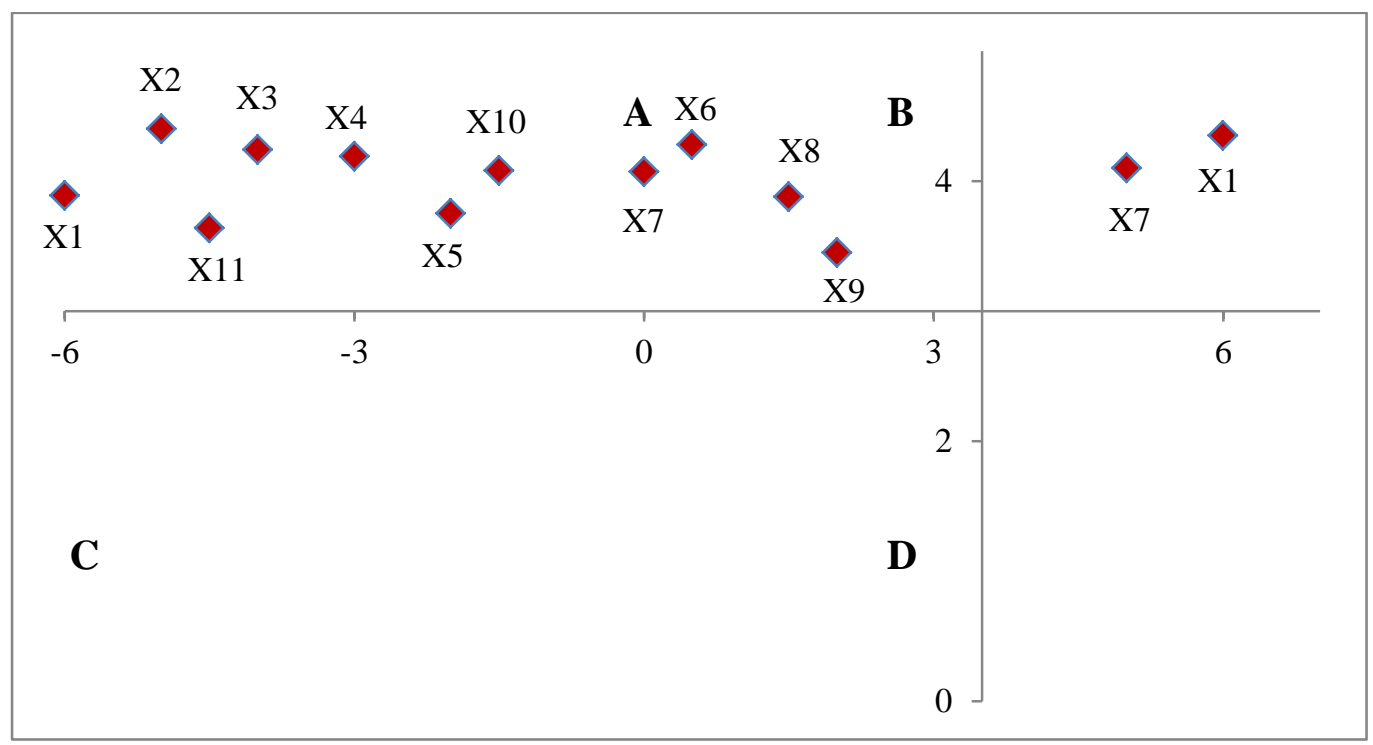

Gambar 1. Diagram Kartesius antara tingkat kepentingan dan kinerja Sumber: Data olahan (2016)

Kuadran I merupakan kuadran yang memiliki tingkat kepuasan masih sangat rendah sehingga menjadi prioritas utama untuk dilakukan perbaikan. Terdapat 10 atribut yang masuk ke dalam kuadran I, dapat diurutkan sesuai tingkat prioritasnya adalah sebagai berikut : atribut lingkungan yang bersih, atribut suasana yang mendukung untuk berolahraga, atribut fasilitas toilet, atribut jalan khusus untuk pengguna kursi roda, atribut fasilitas ibadah, atribut tersedianya kursi-kursi untuk beristirahat, atribut mendapatkan informasi/brosur, atribut adanya penjaga pantai, atribut rambu-rambu penunjuk arah, atribut area parkir dan atribut fasilitas gawat darurat.

Kuadran II merupakan kuadran yang diharapkan oleh pengunjung dan atribut-atribut tersebut telah sesuai dengan yang dirasakan oleh pengunjung. Atribut pada kuadran II juga dapat diurutkan sesuai tingkat prioritas untuk dipertahankan yaitu : atribut iklim udara pantai yang segar dan tersedianya café/resto. Kuadran III merupakan kuadran dengan prioritas rendah yang diartikan bahwa kuadran ini memuat atribut-atribut yang dianggap kurang penting oleh pengunjung dan pada kenyataannya kinerjanya tidak terlalu istimewa.Hasil penelitian tidak menunjukkan adanya atribut-atribut yang masuk ke dalam 
kuadaran III. Begitupun sama halnya untuk kuadran IV, tidak terdapat atributatribut yang masuk kedalam kuadran IV dimana kuadran IV mempunyai tingkat kepentingan yang rendah, tetapi memiliki tingkat pelaksanaan kinerja tinggi. Pengurutan atribut menurut tingkat prioritas untuk dikurangi kinerjanya karena dianggap berlebihan.

\section{KESIMPULAN}

Hasil perhitungan antara tingkat kepentingan dan kinerja pengunjung Pantai Ancol menunjukkan adanya ketidaksesuaian antara harapan dengan persepsi mereka. Maka dengan demikian atribut-atribut yang ada belum mampu memberikan kepuasan terhadap pengunjung Pantai Ancol. Dari sisi Diagram Kartesius, menunjukkan terdapat 11 atribut yang masuk ke dalam Kuadran I dan terdapat 2 atribut yang masuk ke dalam Kuadran II, sedangkan tidak terdapat satu pun atribut yang masuk ke dalam kuadran III dan IV. Atribut yang ideal terdapat pada kuadran II yaitu untuk atribut mengenai iklim udara pantai yang segar dan tersedianya café/resto.

\section{DAFTAR RUJUKAN}

Alegre, Joaquin dan Garau, Jaume. (2010). Tourist Satisfaction and Dissatisfaction, Annal of Tourism Research, Vol 27, No. 1, pp. 52-79.

Ali,Hasan.(2008). Marketing. Yogyakarta.Media Pressindo.

Ani Wijayanti Suhartono. (2004), Pentingnya Perilaku Konsumen dalam Menciptakan Iklan yang Efektif.

Buchari, Alma. (2008). Manajemen Pemasaran dan Pemasaran Jasa. Bandung: Alfabeta

Kotler dan Keller. (2009). Manajemen Pemasaran. Edisi 13.Jilid 1. Alih Bahasa. Bob Sabran. Erlangga. Jakarta.

Morrisan. (2007). Periklanan Komunikasi Pemasaran Terpadu, Jakarta: Ramdina Prakarsa

Pitana, I G., Gayatri, PG. (2005). Sosiologi Pariwisata. Penerbit Andi Yogyakarta. 
Robbins, Stephen P., Timoty A. Judge. (2008). Perilaku Organisasi. Jakarta: Salemba Empat.

Sugihartono, dkk. (2007). Psikologi Pendidikan. Yogyakarta: UNY Press.

Waidi. (2006). The Art of Re-engineering Your Mind for Success. Jakarta: Gramedia.

Wei, S. and Millman, A. (2002). The impact of participation in activities while on vacation on seniors' psychological well-being: a path model analysis. Journal of Hospitality and Tourism Research 26. 